\title{
Analysis of the Influence of Road Infrastructure, Electrical Infrastructure and Health Infrastructure on Economic Growth with Investment as a Moderating Variable in Indonesia
}

\author{
Tohap Parulian ${ }^{1}$, A. Mahendra ${ }^{2}$ \\ ${ }^{1}$ Faculty of Economics and Business at Universitas Medan Area, Indonesia \\ ${ }^{2}$ Faculty of Economics at Universitas Katolik Santo Thomas, Indonesia \\ Corresponding Author: Tohap Parulian
}

DOI: https://doi.org/10.52403/ijrr.20220155

\begin{abstract}
This research is intended to know the influence of Road Infrastructure, Electrical Infrastructure, and Health Infrastructure with Investment as a moderating variable in Indonesia during the period 2004-2020. The multiple regression analysis conducted estimates. The data used in this study were secondary, consisting of Road Infrastructure, Electrical Infrastructure, and Health Infrastructure to Economic Growth for the year 2004-2020. The results of this research that the Road Infrastructure, Electrical Infrastructure, and Health Infrastructure variables partially have a significant effect on the variables of the Economic Growth in Indonesia. In addition, based on simultaneous test (F test), Road Infrastructure, Electrical Infrastructure, and Health Infrastructure have a significant effect on the variables of the economic growth simultaneously. The investment cannot moderate the relationship between Road Infrastructure, Electrical Infrastructure, and Health Infrastructure on Economic Growth.
\end{abstract}

Keywords: Road Infrastructure, Electrical Infrastructure, Health Infrastructure, Investment, and Economic Growth

\section{INTRODUCTION}

Economic growth is an economic problem in the long term. High and sustainable economic growth is an important factor for the continuity of economic development. Economic growth also explains the achievement of a country's/region's economic development from period to period. According to Sukirno (2011), in actual economic activity, economic growth means the development of the production of goods and services in a country such as an increase in the number of industrial goods production, infrastructure development, an increase in the number of schools, an increase in the production of the service sector and an increase in the production of capital goods. In macro analysis, the level of economic growth achieved by a country is measured by the development of real national income achieved by a country (Norlita, 2018).

Future infrastructure development needs to be built optimally so that the integration and consolidation of development can be maximally utilized and built with the most efficient cost possible. It is very important to be underlined considering the huge need for overall development so that a large amount of money is required. Besides, it should also be remembered that sustainable infrastructure development requires large investment costs and high operating and maintenance costs in its use (Diwan, 2014).

Infrastructure is the driving force of economic growth. Infrastructure is seen as 
the locomotive of national and regional development from public and private financing allocation. Infrastructure also has an important effect on improving the quality of life and human welfare, including increasing consumption values, increasing labour productivity and access to employment opportunities, and increasing real prosperity. Infrastructure also has an important influence in increasing consumption value, labour productivity, and access to employment. Natural characteristics and population distribution patterns influence the required nature and type of infrastructure. Infrastructure is needed to increase competitiveness, encourage more investment, production, and trade activities, and accelerate equitable development to reduce poverty and unemployment rates. (Atmaja \& Mahalli).

The Global Competitiveness Report 2019 compiled by the World Economic Forum (WEF) states that Indonesia ranks 72 out of 141 countries in infrastructure development. This sequence shows that the condition of Infrastructure in Indonesia is still weak, marked by the lack of quality and quantity of existing infrastructure, impacting Indonesia's economic growth, which is running inefficiently. Especially during the COVID-19 pandemic that is currently attacking the world, appropriate policy responses need to be taken so that the impact of the pandemic does not plunge the Indonesian economy into a deeper recession (Aprillia).

Infrastructure development during the Covid-19 pandemic is considered to need to pay attention to several things, especially to support national economic recovery. Prior to the reallocation, the PUPR Ministry's budget reached Rp. 120.21 trillion. The allocation is quite large because infrastructure development is still the government's focus. However, due to the Covid-19 pandemic, the PUPR Ministry's budget was cut by Rp. 44.58 trillion, leaving Rp. 75.63 trillion in 2020 (Yasa, 2020).

Many studies show a close relationship between the availability of infrastructure and Gross Domestic Product (GDP) growth. The results of a World Bank study (1994), cited by Santosa (2005), concluded that the elasticity of GDP towards Infrastructure (percentage change in GDP growth per capita as a result of a one per cent increase in infrastructure availability) in various countries varies from 0.07 to 0.44 . The World Bank also found evidence of a strong correlation between the availability of infrastructure, particularly paved roads, electricity, telecommunications, access to clean water, and GDP per capita. Empirically and intuitively, it can be said that infrastructure investment greatly influences the economic growth of a country or region.

Road infrastructure is a locomotive to drive economic development in urban areas and rural areas or remote areas. The infrastructure sector can create jobs that absorb many workers through the project. In addition, infrastructure is a pillar determining the smooth flow of goods, services, people, money, and information from one market zone to another. This condition will allow the prices of goods and services to be cheaper to be purchased by most Indonesians whose incomes are still low. Thus, the circulation of goods, services, people, money, and information also determines market price movements. In other words, that road infrastructure neutralizes the prices of goods and services between regions (between cities and villages) (Prapti, 2015).

Electricity infrastructure plays an important role in economic growth. In this modern era, all fields of human activity require the benefits of electrical energy for both household activities, education, health, industry, and almost all other activities. Lack of electrical energy will result in production process activities being hampered so that the amount of production will decrease and result in decreased income. Electrical infrastructure can also affect both directly and indirectly, to increase household and industrial 
production in order to maximize output (Sugiharto, 2019).

The World Health Organization defines health as a state of complete physical, mental and social well-being and not merely the absence of disease or infirmity. Health services through hospitals and health centres and other health services are expected to improve the quality of health that reaches the entire community to realize equitable health development. The development of health infrastructure, both in quantity and quality, will encourage the improvement of the quality of human resources so that the human development index and economic growth will also increase because health is one of the indicators (Pane, 2020).

The availability of economic infrastructures such as roads, clean water, and electricity has a direct or indirect effect on economic productivity, such as an increase in the amount of output produced, the availability of job opportunities, as well as the development of economic sectors, which will ultimately affect economic growth in a region. This impact has prompted the government to improve infrastructure to increase the accessibility and traffic of goods and people to support all citizens' socio-economic activities (Arafah, 2017).

High economic growth can indicate the country's success in carrying out the wheels of development, which can be fully utilized to improve its people's welfare. Economic development requires investment support which is one of the main sources of economic growth. Investment activities generate investments that will continue to increase the capital stock. Furthermore, the increased capital stock will increase productivity, production capacity, and quality, encouraging economic growth and increasing employment (Astuti, 2018). Investment in this study is a moderating variable to determine whether the investment can strengthen or weaken the relationship of road infrastructure, electricity infrastructure, and health infrastructure to economic growth.

The relationship between infrastructure and economic growth in the debate until now there are at least 2 opinions regarding the influence of infrastructure on economic growth based on the results of each research. The first opinion states that the influence of infrastructure on economic growth is positive. In contrast, the second opinion says that the influence of infrastructure on economic growth is not significant or even negative. The debate among economists and public policymakers regarding the influence of infrastructure on economic growth is still ongoing (Gustina, 2018). Therefore, based on the description of the background above, the authors are interested in conducting further research on the Analysis of the Influence of Road Infrastructure, Electrical Infrastructure, and Health Infrastructure on Economic Growth with Investment as a Moderating Variable in Indonesia.

\section{Framework}

Following the description of the background of the problem, literature review, and previous research, a conceptual research framework prepares as follows:

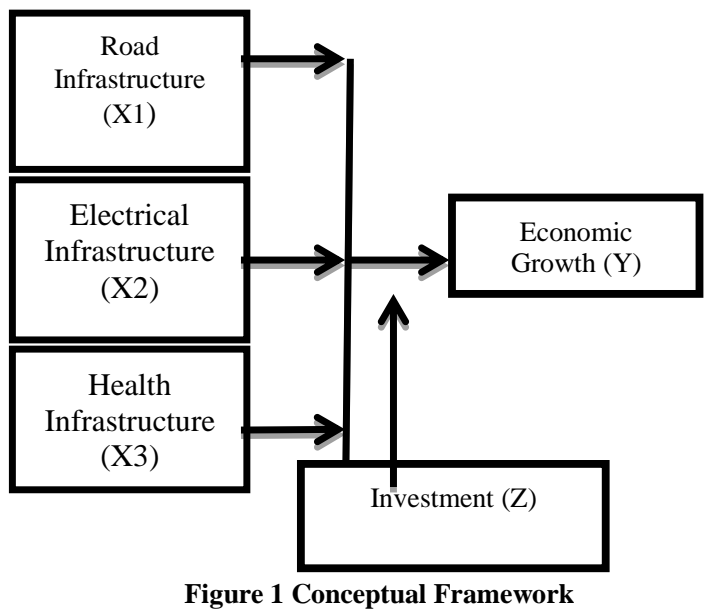

Theoretical Framework and Relationship Between Variables

1. The Effect of Road Infrastructure on Economic Growth

An increase in population will stimulate an increase in the demand for 
goods and services. Where according to Law Number 38 of 2004 concerning Roads where roads act as infrastructure transportation which has an important role in the economy which is the lifeblood of life society, nation and state, socio-culture, environment, politics, defence, and security and used for the greatest prosperity of the people, as an infrastructure for the distribution of goods and is a unified road network system connecting and improving an area.

Mainly transportation infrastructure. Roads are one of the most important indicators for investors to invest in an area. By the function of infrastructure as a stimulus for economic growth, investors will evaluate the existence of infrastructure transportation from two sides. Namely, investors are interested in investing their capital if it is available adequate transportation infrastructure (investment follows the ship), and investors are interested in increasing its investment if the transportation infrastructure builder continues to be developed in line with economic development (ship follows the investment), infrastructure limitations cause existing companies will not be encouraged to expand of investors. New investors are also not interested in making investments that affect the Gross Regional Domestic Product (PDR). economic growth (Iriyena et al, 2019).

\section{The Effect of Electrical Infrastructure on Economic Growth}

In today's modern era, electricity is an important requirement for the general public because every human activity uses electricity. By always increasing the installation of electricity for economic activities that produce quality output, it will increase production. The increase in electrical energy consumption is inseparable from the continued improvement in economic growth and the increasing number of people (Yanti, 2018). Prasetyo (2009) supports this theory, stating that electricity infrastructure has a significant positive effect.

\section{The Effect of Health Infrastructure on Economic Growth}

The fulfilment of good and adequate quality of health infrastructure will improve the quality of health of the population in Indonesia. The results of this study follow the opinion put forward by Robert Fogel (1990), which states that countries with low health and education conditions face more severe challenges to achieve sustainable growth when compared to countries with better health and education conditions. Increasing economic welfare due to increasing age is very important (Amalia, 2019).

\section{Investment can moderate the Road Infrastructure, Electrical Infrastructure, and Health Infrastructure on Economic Growth in Indonesia}

The growth of investment in the electricity, gas, and clean water sectors has the largest impact on changes in total output. In contrast, the transportation and communication sector have the largest impact on total income and employment changes. In order to increase the role of Infrastructure in Indonesia, the government should make more efforts to encourage its production capacity because its ability is still lacking in providing inputs for other sectors, including by building the right infrastructure projects as well as overcoming various investment obstacles to attract investors' interest to invest in the sector (Permana, 2009).

H1: Road Infrastructure has a positive and significant effect on Economic Growth.

$\mathrm{H} 2$ : Electrical Infrastructure has a positive and significant effect on Economic Growth. H3: Health Infrastructure has a positive and significant effect on Economic Growth.

H4: Road Infrastructure, Electrical Infrastructure, Health Infrastructure have a positive and significant effect on the Economic Growth 
H5: Investment can moderate the Road Infrastructure, Electrical Infrastructure and Health Infrastructure on Economic Growth in Indonesia

\section{RESEARCH METHODS}

This type of research includes the kind of quantitative research. The approach used is causality and inferential. This study uses statistical analysis to test the hypothesis (Sugiyono, 2017). Research is conducted with a causal research approach to investigate cause-and-effect relationships by observing the effects that occur and the possible factors (causes) that cause these effects.

The population in this study are Road Infrastructure, Electrical Infrastructure, Health Infrastructure, Investment, and Economic Growth. The sample is part or representative of the population that is the object of research. The sample in this study is Road Infrastructure, Electrical Infrastructure, Health Infrastructure, Investment, and Economic Growth in Indonesia from 2004 to 2020.

\section{RESULT AND DISCUSSION Normality Test}

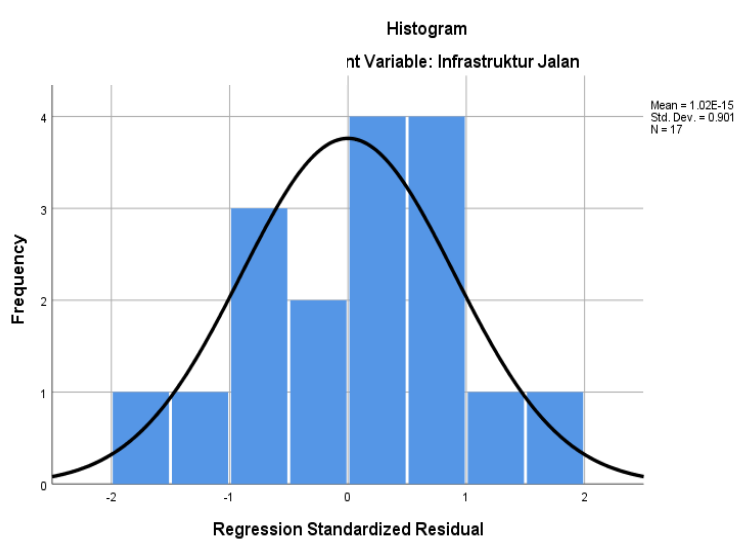

Figure 2 Histogram Graph Normality Test Results Source: Calculation Results of Eviews 10

Based on Figure 1 above, it can be seen that the data distribution is normal and meets the normality assumption. It can be seen from the formed line, which looks to have a bell shape.

\section{Linear regression of Road Infrastructure, Electrical Infrastructure and Health Infrastructure on Economic Growth in Indonesia}

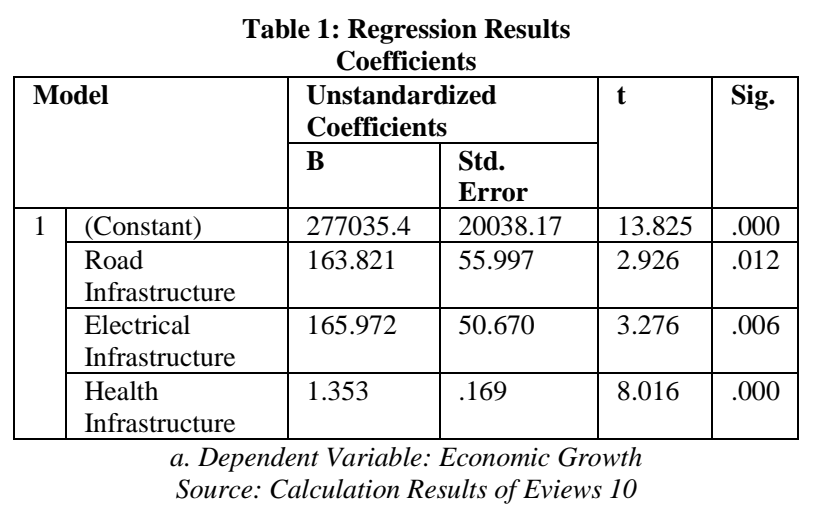

From the regression results above, the estimation results model can be formed as follows:

$\mathrm{Y}=277035.4+163.821 \mathrm{X} 1+165.972 \mathrm{X} 2$ $+1.353 \mathrm{X} 3$

\section{Model Interpretation}

Based on the estimation model above, it can be explained that the effect of the independent variables, namely Road Infrastructure (X1), Electrical Infrastructure (X2), and Health Infrastructure (X3), on Economic Growth in Indonesia is as follows:

\section{Road Infrastructure}

Road Infrastructure has a positive effect on Economic Growth in Indonesia. It is indicated by the regression coefficient $\mathrm{X} 1$, which is 163.821 . It means that with every $1 \%$ increase in road infrastructure, 
Tohap Parulian et.al. Analysis of the influence of road infrastructure, electrical infrastructure and health infrastructure on economic growth with investment as a moderating variable in Indonesia.

economic growth will increase by 163.821 $\%$ (ceteris paribus).

\section{Electrical Infrastructure}

Electrical infrastructure has a positive effect on Economic Growth in Indonesia. It is indicated by the regression coefficient X1, which is 165.972 . It means that with every $1 \%$ increase in electrical infrastructure, economic growth will increase by $165.972 \%$ (ceteris paribus).

\section{Health Infrastructure}

Health Infrastructure has a positive effect on Economic Growth in Indonesia. It is indicated by the value of the regression coefficient $\mathrm{X} 3$, which is 1.353 . It means that with every $1 \%$ increase in Health Infrastructure, economic growth will increase by $1.353 \%$ (ceteris paribus).

\section{Individual Regression Coefficient Testing (Statistical t-Test) \\ 1. Road Infrastructure}

For the Road Infrastructure variable, the t-count value is 2.926 with a probability (significance) value of 0.012 . Thus $\mathrm{Ha}$ is accepted, because the probability value is smaller than the value of $0.05(0.012<0.05)$ and t-count $>$ - t-table (2.926> 2.160). It means that it can be concluded that the Road Infrastructure variable has a significant effect on the variable of economic growth in Indonesia by testing at the $95 \%(=5 \%)$ confidence level.

\section{Electrical Infrastructure}

For Electrical Infrastructure, the tvalue is 3.276 with a probability (significance) value of 0.006 . Thus, $\mathrm{Ha}$ is accepted, because the probability value is smaller than the value $0.05(0.006<0.05)$ and the t-count $>$ t-table $(3.276>2.160)$. It means that it can be concluded that the Electrical Infrastructure variable has a significant effect on the variable of economic growth in Indonesia by testing at the $95 \%$ confidence level $(=5 \%)$.

\section{Health Infrastructure}

For the investment variable, the tcount value is 8.016 with a probability (significance) value of 0.000 . Thus $\mathrm{Ha}$ is accepted, because the probability value is smaller than the value $0.05(0.000>0.05)$ and the t-count <t-table $(0.817>2.160)$. It means that it can be concluded that the Health Infrastructure variable has a significant effect on the variable of economic growth in Indonesia by testing it at the $95 \%$ confidence level $(=5 \%)$.

\section{Simultaneous Testing of Regression Coefficients (Statistical F Test)}

\begin{tabular}{l} 
Table 2: Anova test \\
\begin{tabular}{|l|l|l|l|}
\hline Model & F & Sig. \\
\hline \multirow{3}{*}{1} & Regression & 32.992 & $.000^{\mathrm{b}}$ \\
\cline { 2 - 4 } & Residual & & \\
\cline { 2 - 4 } & Total & & \\
\hline
\end{tabular} \\
\hline
\end{tabular}

Based on the output of the SPSS program, the F-count value is 18.486 with a probability (significance) value of 0.000 . Thus Ha is accepted, because the value of Fcount> F-table $(32.992>3.41)$ and the probability value (significance) is smaller than the value of $0.05(0.000<0.05)$. It means that it can be concluded that the variable X1 (Road Infrastructure), variable $\mathrm{X} 2$ (Electrical Infrastructure), and variable X3 (Health Infrastructure) have a significant (significant) effect on Economic Growth $(\mathrm{Y})$ at $95 \%$ confidence level $(=5 \%)$.

\section{Coefficient of Determination $\left(\mathbf{R}^{2}\right)$}

\begin{tabular}{|l|l|l|l|}
\multicolumn{4}{c}{ Table 3: Coefficient of Determination } \\
\hline Model & R & R Square & Adjusted R Square \\
\hline 1 & $.908 \mathrm{a}$ & .825 & .800 \\
\hline \multicolumn{4}{|c|}{ Source: Calculation Results of SPSS } \\
\hline
\end{tabular}

Based on the results of the SPSS program output shows that the R-square value is 0.825 , which means that the variables X1 (Road Infrastructure), variable $\mathrm{X} 2$ (Electrical Infrastructure), and variable X3 (Health Infrastructure) are jointly able to explain the Economic Growth by $82.5 \%$. In comparison, the remaining $17.5 \%$ is explained by new variables that are not included in the model estimation. 
Tohap Parulian et.al. Analysis of the influence of road infrastructure, electrical infrastructure and health infrastructure on economic growth with investment as a moderating variable in Indonesia.

Moderating Test Results (Residual Test)

\begin{tabular}{|c|c|c|c|c|c|}
\hline & & Table 4 & fficient & & \\
\hline \multirow{2}{*}{\multicolumn{2}{|c|}{ Model }} & \multicolumn{2}{|c|}{$\begin{array}{l}\text { Unstandardized } \\
\text { Coefficients }\end{array}$} & \multirow[t]{2}{*}{$\mathbf{t}$} & \multirow[t]{2}{*}{ Sig. } \\
\hline & & B & $\begin{array}{l}\text { Std. } \\
\text { Error }\end{array}$ & & \\
\hline 1 & (Constant) & 6849.507 & 8116.767 & .844 & .413 \\
\hline & $\begin{array}{l}\text { Road } \\
\text { Infrastructure }\end{array}$ & .074 & .054 & 1.376 & .191 \\
\hline & $\begin{array}{l}\text { Electrical } \\
\text { Infrastructure }\end{array}$ & -.029 & .026 & -1.108 & .286 \\
\hline & $\begin{array}{l}\text { Health } \\
\text { Infrastructure }\end{array}$ & 0.380 & .024 & 7.414 & .000 \\
\hline
\end{tabular}

\begin{tabular}{|c|c|c|c|c|c|}
\hline \multirow{3}{*}{\multicolumn{2}{|c|}{ Model }} & \multirow{2}{*}{\multicolumn{2}{|c|}{$\begin{array}{l}\text { Unstandardized } \\
\text { Coefficients }\end{array}$}} & \multirow{3}{*}{$\mathbf{t}$} & \multirow{3}{*}{ Sig. } \\
\hline & & & & & \\
\hline & & B & Std. Error & & \\
\hline \multirow[t]{2}{*}{1} & (Constant) & -109.784 & 452.077 & -.243 & .811 \\
\hline & EcoGrowth & .024 & .000 & 3.080 & .008 \\
\hline
\end{tabular}

Source: Calculation Results of Eviews 10

Based on the results of the residual test in table 3, the moderation regression equation is obtained as follows:

\section{$\mathrm{Z}=6849.507+0.074 \mathrm{X} 1-0.029 \mathrm{X} 2+$ $0.380 \times 3$ \\ $|e|=-109.784+0.024 Y$}

A variable is moderating if the $\mathrm{P}$ Value (Sig) $<0.05$ and the negative parameter coefficient value. Based on Table 3 , the results of the residual test show that the significant value of 0.008 is smaller than $\alpha=0.05(0.008<\alpha=0.05)$ and the positive coefficient value is $(0.024)$, it can be concluded that the investment is not able to moderate the relationship between the Road Infrastructure. Electrical Infrastructure, and Health Infrastructure on Economic Growth. In other words, the Investment variable is not a moderating variable in this study (H5 is unacceptable).

\section{CONCLUSION}

Based on the results of data analysis and research discussion, the following conclusions can be drawn:

1. From the results of the $F$ test, it is concluded that the Road Infrastructure, Electrical Infrastructure, and Health Infrastructure during the period 2004 to 2020 have a significant simultaneous effect on Economic Growth in Indonesia at a 5\% significance level. Thus the research hypothesis is accepted.

2. Based on the partial test (t-test), the variables of road infrastructure, electrical infrastructure, and health infrastructure have a partially significant effect on the variable of economic growth in Indonesia by testing at the 95\% confidence level $(=5 \%)$.

3. The Investment variable is unable to moderate the relationship between Road Infrastructure, Electrical Infrastructure, and Health Infrastructure to Economic Growth in Indonesia

4. The coefficient of determination (R) is 0.825 , which means that the variables X1 (Road Infrastructure), X2 (Electrical Infrastructure), and X3 (Health Infrastructure) together can explain variations in Economic Growth in Indonesia of $82.5 \%$. In comparison, the remaining $17,5 \%$ is explained by new variables not included in the model estimation.

\section{Acknowledgement: None}

\section{Conflict of Interest: None}

\section{Source of Funding: None}

\section{REFERENCES}

1. Amalia, Dyah. 2019. Analisis Pengaruh Infrastruktur Terhadap Pertumbuhan Ekonomi (Studi Pada 33 Provinsi Di Indonesia Tahun 2008 - 2017). Universitas Brawijaya Malang.

2. Aprillia, Angella \& Tarigan, Anton. Dampak Pandemi Terhadap Pembangunan Infrastruktur.

https://kpbu.kemenkeu.go.id/read/11121273/umum/kajian-opini-publik/dampakpandemi-terhadap-pembangunaninfrastruktur

3. Arafah, Sri Yara. 2017. Analisis Pengaruh Infrastruktur Jalan, Listrik dan Pendidikan Terhadap Pertumbuhan Ekonomi Di Kota Medan. Universitas Sumatera Utara.

4. Astuti, Puspasari Windy. 2018. Analisis Pengaruh Investasi Terhadap Pertumbuhan Ekonomi (Studi Pada 33 Provinsi Di 
Tohap Parulian et.al. Analysis of the influence of road infrastructure, electrical infrastructure and health infrastructure on economic growth with investment as a moderating variable in Indonesia.

Indonesia). Jurnal Ilmiah. Universitas Brawijaya, Malang.

5. Atmaja, Harry Kurniadi \& Mahalli, Kasyful. Pengaruh Peningkatan Infrastruktur Terhadap Pertumbuhan Ekonomi Di Kota Sibolga.

6. Diwan. 2014. Pengaruh Pembangunan Infrastruktur Terhadap Pertumbuhan Ekonomi Di Kabupaten Aceh Barat. Universitas Teuku Umar

7. Gustina, Wika. 2019. Pengaruh Infrastruktur Terhadap Pertumbuhan Ekonomi Kab.Muaro Jambi (Studi Kasus Kumpeh Ulu). Universitas Islam Negeri Sulthan Thaha Saifuddin.

8. Iriyena, Paulus; Naukoko, Amran $\mathrm{T}$ \& Siwu, Hanly F DJ. 2019. Analisis Pengaruh Infrastruktur Jalan Terhadap Pertumbuhan Ekonomi Di Kabupaten Kaimana 20072017. Jurnal Berkala Ilmiah Efisiensi Volume 19 No. 02.

9. Ma'ruf, Youdhi Permadi. 2013.Pengaruh Investasi Infrastruktur Jalan Terhadap Pertumbuhan Ekonomi Wilayah Di Kabupaten Pesisir Selatan Provinsi Sumatera Barat. Universitas Sumatera Utara.

10. Norlita, Vela. 2018. Pengaruh Investasi, Tenaga Kerja dan Infrastruktur Terhadap Pertumbuhan Ekonomi Di Pulau Jawa Tahun 2006-2015. Universitas Negeri Yogyakarta.

11. Pane. 2020. Pengaruh Pembangunan Infrastruktur Kesehatan, Pendidikan dan Jumlah Penduduk Terhadap Pertumbuhan Ekonomi Di Sumatera Utara. Jurnal Sekolah Vol 4 (2) Maret.

12. Permana, Chandra Darma. 2009. Analisis Peranan dan Dampak Investasi Infrastruktur terhadap Perekonomian Indonesia: Analisis Input-Output. Institut Pertanian Bogor.

13. Prapti, Lulus Rr; Suryawardana, Edy; Triyani, Dian. 2015. Analisis Dampak Pembangunan Infrastruktur Jalan Terhadap
Pertumbuhan Usaha Ekonomi Rakyat Di Kota Semarang. Jurnal Dinamika Sosial Budaya Vol 17 No 1.

14. Prasetyo. 2009. Pengaruh Infrastruktur pada Pertumbuhan Ekonomi Wilayah di Indonesia.

15. Santosa, W \& Van Roy, S. 2005. Korelasi Investasi Infrastruktur Jalan Terhadap Pertumbuhan Ekonomi Regional. Universitas Katolik Parahyangan.

16. Sugiharto. 2019. Analisis Pengaruh Infrastruktur Jalan dan Listrik Terhadap Pertumbuhan Ekonomi Di Kabupaten Lampung Utara Tahun 2007-2016 Dalam Perspektif Ekonomi Islam. Universitas Islam Negeri Raden Intan Lampung.

17. Sugiyono. 2017. Metode Penelitian Kuantitatif, Kualitatif dan R \& D. Bandung : Alfabeta, CV

18. Sukirno, Sadono. 2011. Makro Ekonomi Teori Pengantar Edisi Ketiga. Jakarta : PT Raja Grafindo Persada.

19. Yanti. 2018. Pengaruh Infrastruktur Jalan, Listrik Dan Air Terhadap Pertumbuhan Produk Domestik Regional Bruto Di Kabupaten Gowa Provinsi Sulawesi Selatan. Universitas Muhammadiyah Makassar

20. Yasa, Agne. 2020. Dampak Corona, Strategi Pembangunan Infrastruktur Perlu Penyesuaian. https://ekonomi.bisnis.com/read/20200614/4 5/1252557/dampak-corona-strategipembangunan-infrastruktur-perlupenyesuaian

How to cite this article: Tohap Parulian, A. Mahendra. Analysis of the influence of road infrastructure, electrical infrastructure and health infrastructure on economic growth with investment as a moderating variable in Indonesia. International Journal of Research and Review. 2022; 9(1): 489-496. DOI: https:// doi.org/10.52403/ijrr.20220155 